\title{
歯周疾患とカテプシン $\mathrm{B}, \mathrm{H}$ ，拈よび $\mathrm{L}$
}

\author{
國松和司・市丸英二・加藤伊八 ${ }^{* 1)}$, 山本健二・加藤有三*2)
}

\begin{abstract}
Cathepsins $B, H$ and $L$ activities in gingival crevicular fluid from patients with chronic adult periodontitis To clarify a role of lysosomal cysteine proteinases, cathepsins $\mathbf{B}, \mathrm{H}$ and $\mathrm{L}$ in periodontal tissue destruction, levels of their activities in gingival crevicular fluid (GCF) from patients with chronic adult periodontitis were determined using 4-methyl7-coumarylamide substrates. All of the enzyme activities were positively correlated with the GCF volume, but not with the probing depth. Higher levels of the respective activities were found at sites with more serious signs of periodontal disease. The specific activity of each enzyme in GCF, however, was progressively decreased as the GCF volume increased, indicating the negative correlation between GCF volume and each enzyme activity. The results also suggest that cathepsins $\mathrm{B}, \mathrm{H}$ and $\mathrm{L}$ are selectively released into gingival crevices at a mild stage of the periodontitis and that the levels of these enzymes in the GCF may be clinical parameters that reflect the degree of the periodontal tissue destruction.
\end{abstract}

Kazushi Kunimatsu • Eiji Ichimaru • Ihachi Kato*1), Kenji Yamamoto • Yuzo Kato*2) ${ }^{* 1}$ Department of Periodontology, Nagasaki University School of Dentistry *2) Department of Pharmacology, Nagasaki University School of Dentistry

key words : cathepsin B, cathepsin $H$, cathe psin L, periodontitis gingival crevicular fluid

歯周疾患の発症ならびに進行因子としてプラーク（霜 垢)や歯周ポケット内の細菌は, もっとも重要な存在で あることは周知の事実である。歯周疾患は，まず，これ らの細菌やその代謝産物によって宿主側が刺激され, 非 特異的な炎症としてはじまる。 その後, 宿主側にこれら に対する抗体が産出され，免疫反応を伴う慢性炎症性の 免疫疾患として確立される。歯周疾患の主たる病態が, 歯肉上皮ならびに結合組織などの比較的表層に存在する 歯周組織の破壞と，それに引きつづき起こる歯槽骨の吸 収であることを考劣ると，それらを引き起こす宿主側の 破壊因子と, それらの調節機構の研究は非常に重要であ ると思われる。

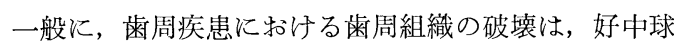
扣よびマクロファージなどの炎症性細胞や線維芽細胞抒 よび上皮細胞などの非炎症性細胞から遊離される多くの リソゾーム性酵素 (たとえばカテプシン群や中性プロ テアーゼ群)ならびに活性酸素などによって，直接ある いは間接に引き起こされるものと考兄られている1

筆者らを含め他の多くの研究者によって, 炎症による 歯周組織の破壊過程を酵素化学的に解明するために, そ の破壊に関与すると考学られている各種プロテアーゼの 同定と定量化が試みられてきた。しかしながら，今日ま で, 本疾患に括ける歯周組織の破壊過程でいかなるプロ

*1) 長崎大学歯学部歯科保存学第二講座

*2) 同 歯科薬理学講座
テアーゼがどのような形で機能しているかなど, プロテ アーゼの機能の詳細については汪とんど解明されていな い.

最近, 歯肉溝滲出液中に検出されるコラゲナーゼ活性 と歯周疾患の病勢の間に相関関係があることが示されて いるが4,5)，炎症局所に扣ける酵素の 調節機構（たとえ ば, インヒビターTIMPなどとの関係)や免疫学的測定 に基づいた酵素量の変化など不明な点が多く残されてい る.

本稿では, 歯周疾患患者の歯肉溝㳒出液に含まれるリ ソゾーム性システインプロテアーゼ, カテプシン $\mathrm{B}, \mathrm{H}$, およびしの活性を測定し，本疾患の病勢との関連性につ いて検討したので，その結果を述べる。

\section{方 法}

(1) 材 料

被検者は, 長崎大学歯学部附属病院第 2 保存科を受診 した患者で, 軽度から高度の歯周炎を有し，全身的疾患 を持たない平均年齢46.6歳(30６2歳)の13名 (男 6 名, 女 7 名)である.被検部位は，X線写真上で明らかな垂 直性の蒾槽骨吸収の認められる歯周ポケット（合計 48 カ 所)を任意に選択した.

(2) 試料の採取

歯肉溝渗出液 (gingival crevicular fluid, GCF) の採取 は以下の要領で行った，まず, 簡易防湿後, 歯肉縁上プ ラークを注意深く除去し，スリーウェイシリンジにてポ 

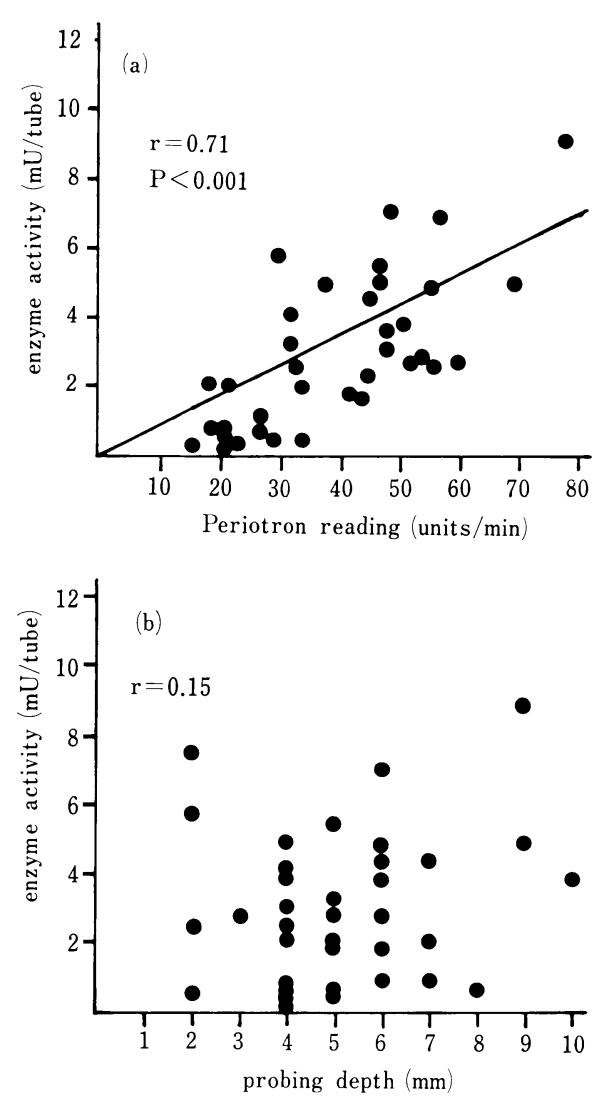

図 1 GCF cathepsin B activity as functions of GCF volume (a) and probing depth (b) in chronic adult periodontitis groups

The GCF volumes were determined by Periotron readings. Cathepsin B activity in GCF collected from sites in patients with periodontitis was determined by using Z-Arg-Arg-MCA as a substrate. Sampling and extraction of the enzyme were carried out as described in "Materials and Methods".

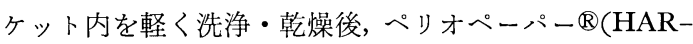
601，Harco）を30秒間霜周ポケット内へわずかに抵抗の 感じられるまで挿入し，貯留 GCFを吸湿除去した．た だちに, 新しいペリオペーパー®を同じ部位に 3 分間静 置したあとに，吸湿採取し，これを歯周ポケット内に流 出してくる GCF 試料とした。採取した GCFは, ペリ オトロン6000®(Harco )にて GCF 量を計測し, あらか じめ水冷して扔いた $300 \mu l$ の $10 \mathrm{mM}$ リン酸緩衝液 $(\mathrm{pH}$ 6.5)に浸し, $0^{\circ} \mathrm{C} て ゙ 5 〜 6$ 時間放置した. その後, 試料 を 5 分間超音波処理にかけ，遠心したあと，上清を抽出 液として実験に供した。

\section{（3）酵素活性の測定および蛋白質定量}

カテプシン B，HおよびLは，それぞれ Z-Arg-ArgMCA, Arg-MCA，および Z-Phe-Arg-MCA を基質と
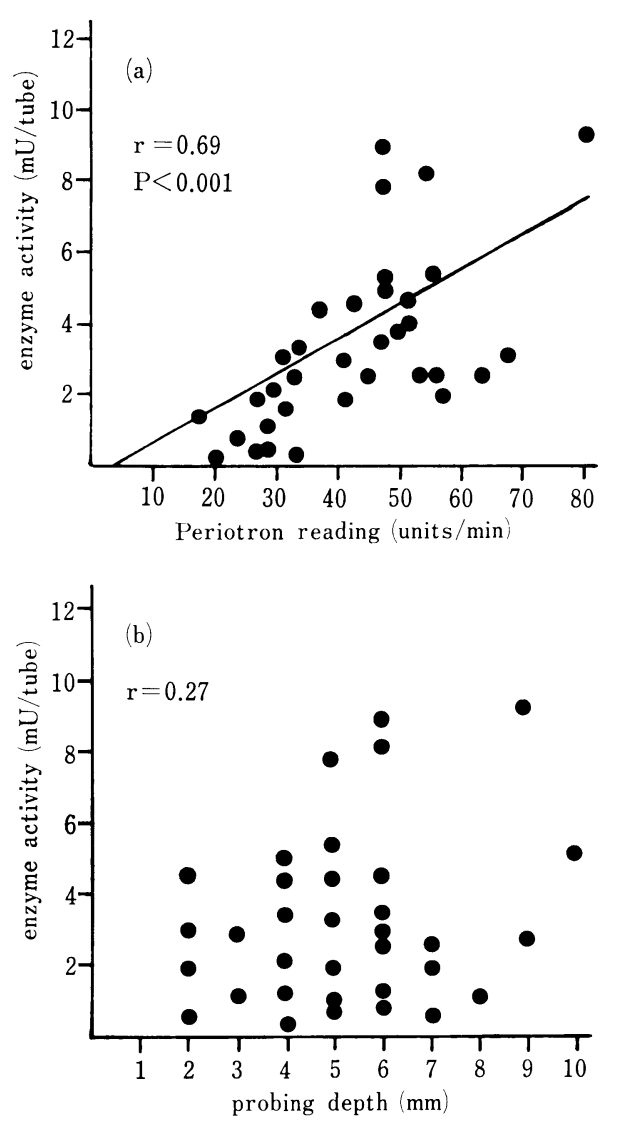

図 2 GCF cathepsin $\mathrm{H}$ activity as functions of GCF volume (a) and probing depth (b) in chronic adult periodontitis groups

Cathepsin $\mathrm{H}$ activity was determined by using Arg-MCA as a substrate. Other details are the same as described in Fig. 1.

して Barrett らの方法 ${ }^{6)}$ に従って測定した. 蛋白質の定 量は Lowry らの方法7)に従って行った.

(4) 歯周ポケットの深さ(PD)の測定

平型両頭のポケット探針 (山浦)を用い, 挿入圧約 $25 \mathrm{~g}$ で測定し, mm 単位で表した.

(5) 統計処理

相関係数の有意差の検定は, Student の $\mathrm{t}$ 検定によっ た。

\section{結 果}

カテプシン Bの GCF 中の活性量は, GCF 量の増加 に比例して増加した(図 $1 \mathrm{a}$ ). ペリオトロンでのニニッ ト值が200ときの活性值は，1.2 $\mathrm{mU} /$ tube，ユニット值 55のときには $4.8 \mathrm{mU} /$ tube となり, 約 4 倍に増加した. カテプシン $\mathrm{B}$ の活性量の変化と $\mathrm{GCF}$ 量の変化の間には 非常に高い相関 (相関係数 $0.71, \mathrm{P}<0.001$ ) が認められ た.これに対し, カテプシン Bの活性量の変化と PDの 

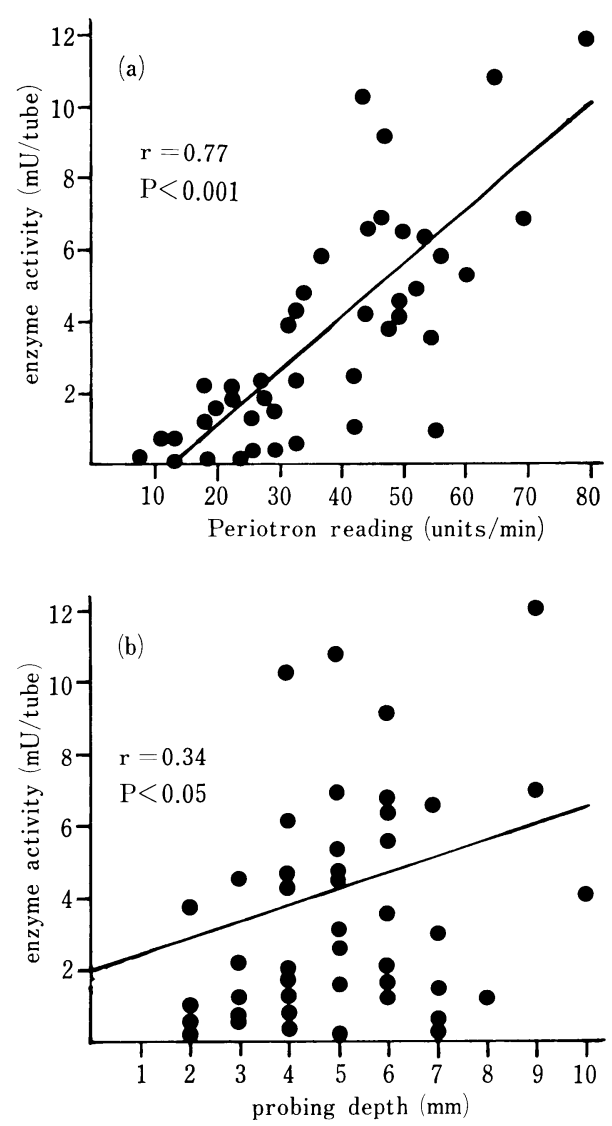

図 3 GCF cathepsin L activity as functions of GCF volume (a) and probing depth (b) in chronic adult periodontitis groups

Cathepsin L activity was determined by using Z-Phe-Arg-MCA as a substrate. Other details are the same as described in Fig. 1.

変化の間にはほとんど相関が認められなかった(図 $1 \mathrm{~b})$. また，カテプシン Hの活性量は，カテプシン Bの場合と 同様, GCF 量の増加に比例して増加した(図 $2 \mathrm{a}$ )(相関 係数 $0.69, \mathrm{P}<0.001)$. これに対し, PD との間には相 関は認められなかった(図 $2 \mathrm{~b}$ ).

一方, カテプシン L の活性量は, 上記二つの酵素と同 様に, GCF 量の増加に比例して増加したが， その相関 係数は 0.77( $\mathrm{P}<0.001)$ ともっとも高い相関を示した(図 $3 \mathrm{a})$.また，カテプシンLは，PDに関しても低いなが らも相関を示した(相関係数 $0.34, \mathrm{P}<0.05$ ) (図 $3 \mathrm{~b}$ ).

つぎに，各酵素の歯周ポケットへの渗出の仕方を検討 するために, GCF 中に含まれる蛋白質当りの活性值(比 活性值)を求めた。 カテプシンBは図 4 に示したごとく, 全活性量のパターンと違って, GCF 量の増加に逆比例 して比活性值は減少した。このときの相関係数はー0.43 $(\mathrm{P}<0.02)$ で有意な相関が認められた．カテプシン $\mathrm{B}$ と 同様の結果は, カテプシンH执よ゙Lでも得られた（図
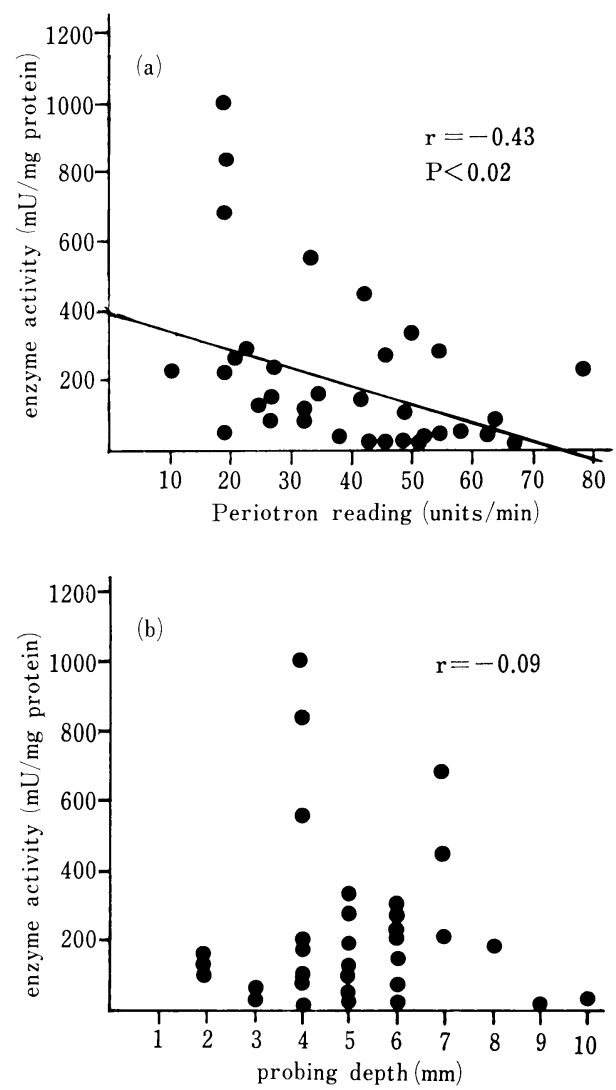

図 4 specific activity of GCF cathepsin B as functions of GCF volume (a) and probing depth (b) in chronic adult periodontitis groups

The specific activity is defined as nmol of 7amino-4-methylcoumarin (MCA) released from $\mathrm{Z}_{-}$ Arg-Arg-MCA per min per mg GCF protein.

5 拈よび 6$)$ ， それぞれの相関係数は， カテプシンHで $-0.39(\mathrm{P}<0.05)$, カテプシン L でー0.39( $\mathrm{P}<0.02)$ で あり, 明らかに GCF 量の変化と負の相関を示した。 こ れらの結果は, GCF 量が少ない段階, すなわち歯周疾 患の病勢がまだ弱いと思われる段階で，カテプシン B, H扣よびLは濃縮されて歯周ポケット内に遊出している ことを示している.

一方, 各酵素の比活性值と PD 值との間にはまったく 相関が認められなかった。

\section{考察}

日常の臨床に括いて，歯周疾患の診査・診断にもっと もよく用いられるパラメーターは, 歯周ポケットの深さ (PD), 歯肉の炎症状態を示す歯肉炎指数 (GI), 歯肉溝 の滲出液量 $(\mathrm{GCF})$, 歯の動摇の程度やX線写真からの歯 槽骨吸収状態であろう。これらのパラメーターは, 現状 に括ける病勢を把握し，治療をするうえで重要であると 考它らている. 

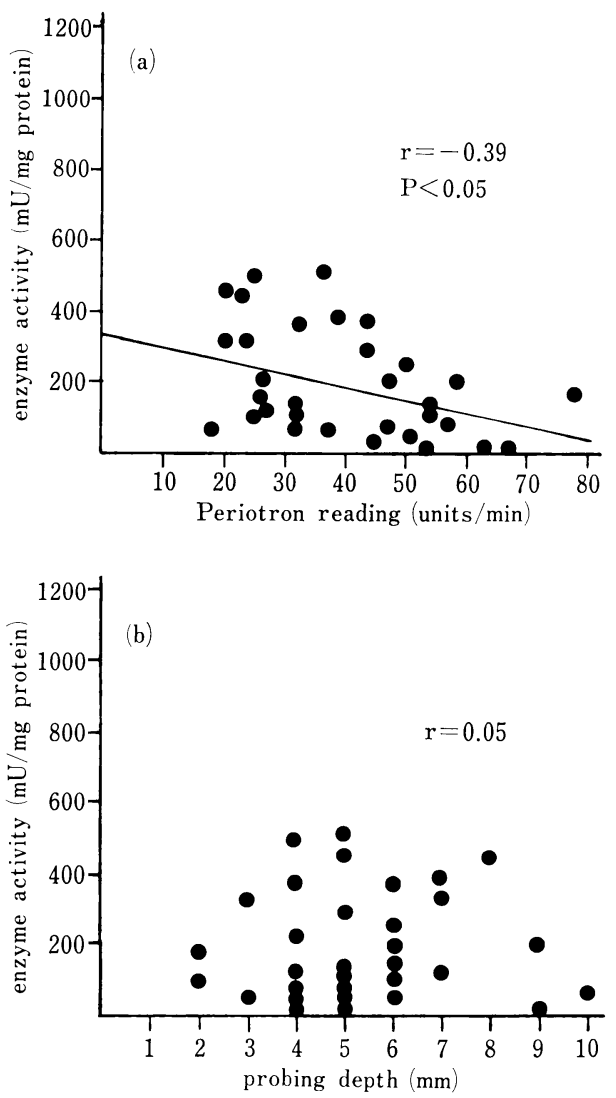

図 5 specific activity of GCF cathepsin $\mathrm{H}$ as functions of GCF volume (a) and probing depth (b) in chronic adult periodontitis groups

The specific activity is defined as nmol of 7-amino4-methylcoumarin(MCA) released from Arg-MCA per min per mg GCF protein.

それゆえこれらパラメーターと GCF 中に含まれる 各種酵素との相関を追究した研究は多い. 特に, PD と の相関を調べたものが多く，PD と相関があると報告さ れた酵素の中には，アルカリ性フォスファターゼ8)， $\beta$ グルクロ ニダーゼ9), エラスターゼ(10), カテプシン $\mathrm{D}^{11,12)}$ およびュラゲナーゼ ${ }^{13)}$ などがある.

本研究の結果は, カテプシン B，H抒よびLのいずれ の酵素も PD との相関はきわめて低いか，臣とんぞ涊め られなかった。これは，PD が過去の炎症による歯周組 織破壞の結果を示すものであって, 必ずしも現状に打け る組織破壊の活性度を反映するものではないという所 見 ${ }^{14)}$ に一致するものである。これは，現状における歯周 組織の破壊の進行度(歯周病変活性度)を正確に把握する ためには，PD 值のみでは不十分であり，他の有効なパ ラメーターの探索が必要であることを示している，GI は, 歯周疾患の有効な臨床パラメーターであるが, 本研 究では, 明らかな歯周組織破壊の認められる初診時の歯
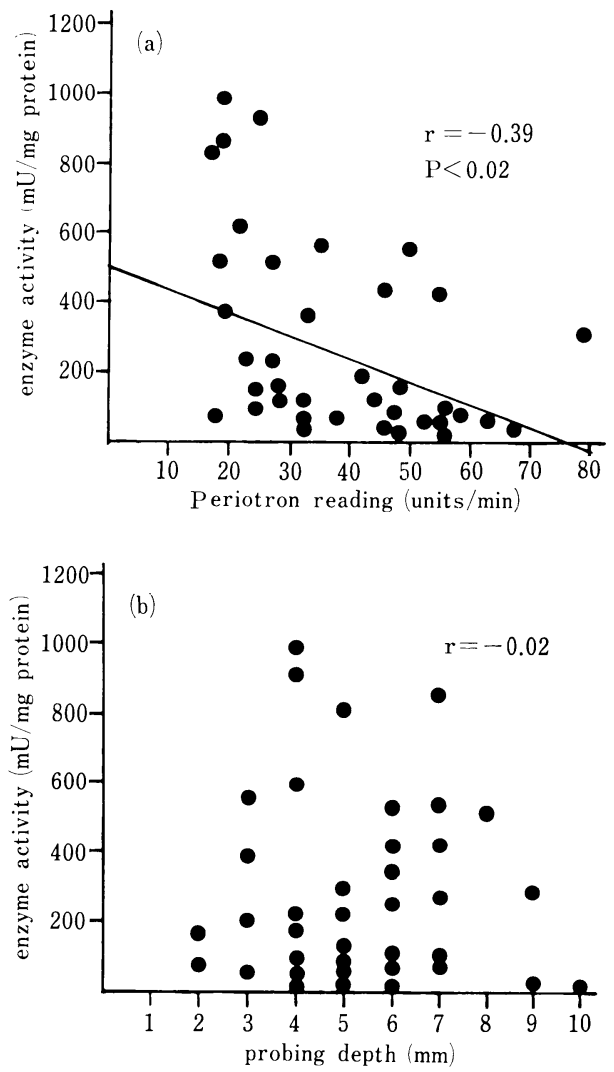

図 6 specific activity of GCF cathepsin L as functions of GCF volume (a) and probing depth (b) in chronic adult periodontitis groups

The specific activity is defined as nmol of 7-amino4-methylcoumarin (MCA) released from Z-PheArg-MCA per min per mg GCF protein.

周ポケットで，しかも，自然出血や排膿の認められない 部位を対象として用いているため， GI 值はすべて 1 か 2 と判定されるものであった。

また，GI 值については，分類の基準が比較的大まか なため, 本研究では, 歯周疾患の成立過程や活性度の詳 細を解析するためには用いることはできなかった。

PD とともに重要視されているもら一つの臨床パラメ ーターに GCF 量がある. GCF は, 微量であるために 注意ぶかい採取技術を要するが，ペリオペーパー®を用 いれば比較的容易に液量を測定することができる。一般 に, GCF 量は歯周疾患の進行程度と相関があるといわ れていることから ${ }^{15)}$ ，多くの研究者によってその中に含 まれるさまざまな成分の解析が試みられてきた。しか し，歯周疾患の病勢変化に伴う GCF 中のプロテアーゼ の動態変化についての検討はほとんどなされていない.

今回の筆者らの結果は, 代表的なりソゾーム性システ インプロテアーゼのカテプシン B , H, 执よびLの活性 
量が，いずれも GCF 量と非常に高い相関を持つことが 示された。これは，これらの䣲素の正確な動態を把握す ることによって，雨周組織の破壊の進行程度を知ること ができることを示唆したものである。また，これらの醅 素の比活性が， GCF 量と負の相関を示したことは，こ れらの酵素が歯周組織の破壊過程の初期の段階で高濃度 飞選択的に霜周ポケット内に遊出してくることを示唆し ている.

今回の実験は, 歯周疾患比ける歯周組織の破壊の程 度と活性度を各種プロテアーゼの動態から把握すること によって, 正確な診断と治療関する情報を得ようとし たものであり, 各酵素の同定と定量化を必須の課題とし ていた. したがって，今回のように酵素活性を指標とし て研究を進める場合，それぞれの酵素を分別できる特異 的基質の存在が必要である。乙かし，今回用いた基質 は，それぞれ特異性は高いものの，カテプシン B 亿対す るものを除けば，必ずしもそれぞれの酵素に対しての唯 一絶対のものではなかった。 また，生体の組織や血中に は多くの内在性インヒビターが存在して括り，それらが 歯肉溝渗出液に含まれている可能性が十分考兄られ，酵 素活性のみによる結果からでは, 各酵素の GCF 中の動 態を正確に把握しているとはいいがたい。るちろん，酵 素活性が検出されるといらことは, 歯周組織の破壊過程 で,これらのプロテアーゼが active な状態で積極的な役 割を果たしていることを強く示唆している点で意義ぶか い.

今後は, 歯周疾患の進行過程に拈ける各醅素の正確な 動態を把握するためには, 活性量の測定とともに, 各酵 素に対する特異抗体を用いた免疫学的定量が必要であ り, 筆者らは, これを今後の課題としている.

本研究の一部は, 文部省科学研究費総合研究 (A) (課 題番号61304054)によって行われた.

\section{文 献}

1) Cimasoni, G.: Crevicular fluid updated. Basel: Karger, 1983, p 84-102.

2) Sandholm, L.: Proteases and their inhibitors in chronic inflammatory periodontal disease. J. Clin. Periodontol. 13: 19-26, 1986.

3) Bartold, P.M., Wiebkin, O.W., Thonard, J.C.: The effect of oxygen-derived free radicals on gingival proteoglycans and hyaluronic acid. J.
Periodont. Res. 19: 390-400, 1984.

4) Kowashi, Y., Jaccard, F., Cimasoni, G.: Increase of free collagenase and neutral protease activities in the gingival crevice during experimental gingivitis in man. Archs oral Biol. 24: 645-650, 1979.

5) Kryshtalskyj, J.E., Sodek, J., Ferrier, J.M.: Correlation of collagenolytic enzymes and inhibitors in gingival crevicular fluid with clinical and microscopic changes in experimental periodontitis in the dog. Archs oral Biol. 31: 21-31, 1986.

6) Barrett, A.J., Kirschke, H.: Cathepsin B, Cathepsin, H., Cathepsin, L.: Methods Enzymol. 80: 535-561, 1981.

7) Lowry, O.H., Rosebrough, N.J., Farr, A.L., Randall, R.J.: Protein measurement with the Folin phenol reagent. J. Biol. Chem. 193: 265275, 1951.

8) Ishikawa, I., Cimasoni, G.: Alkaline phosphatase in human gingival fluid and its relation to periodontitis. Archs oral Biol. 15: 1401-1404, 1970.

9) Bang, J., Cimasoni, G., Held, A.J.: Betaglucuronidase correlated with inflammation in the exudate from human gingiva. Archs oral Biol. 15: 445-451, 1970.

10）中村正一：歯周疾患と歯肉浸出液拉上び唾液中の Protease 活性との関係について。 日歯周誌 21 : 429-434, 1979.

11) Ishikawa, I., Cimasoni, G., Ahmad-Zadeh, C.: Possible role of lysosomal enzymes in the pathogenesis of periodontitis: A study on cathepsin D in human gingival fluid. Archs oral Biol. 17: 111-117, 1972.

12) Lah, T., Skalerič, U., Babnik, J., Turk, V.: Detection of cathepsin L-like proteinase and cathepsin D in gingival fluid. J. Periodont. Res. 21: 504-509, 1986.

13) Golub, L.M., Siegel, K., Ramamurthy, N.S., Mandel, I.D.: Some characteristics of collagenase activity in gingival crevicular fluid and its relationship to gingival disease in humans. J. Dent. Res. 55: 1049-1057, 1976.

14) Haffajee, A.D., Socransky, S.S., Goodson, J.M.: Clinical parameters as predictors of destructive periodontal disease activity. J. Clin. Periodontol. 10: 257-265, 1983.

15) Löe, H., Holm-Pedersen, P.: Absence and presence of fluid from normal and inflamed gingiva. Periodontics 3: 171-177, 1965. 